UDC 621.01

S. Koshel, PhD, Assoc. Prof.,

G. Koshel, PhD, Assoc. Prof.,

Kyiv National University of Technologies and Design, 2 Nemirovich- Danchenko Str., 01011 Kyiv, Ukraine; e-mail: a_koshel@ukr.net

\title{
ANALYSIS OF FOURTH CLASS PLANE MECHANISMS WITH STRUCTURAL GROUPS OF LINKS OF THE SECOND ORDER
}

С.О. Кошель, Г.В. Кошель. Аналіз плоских механізмів четвертого класу з структурними групами ланок другого порядку. Складні багатоланкові плоскі механізми все частіше застосовуються в технологічному обладнанні легкої промисловості. Відсутність універсального способу кінематичного дослідження механізмів четвертого та вище класів дозволяє стверджувати про актуальність робіт з кінематичного аналізу таких багатоланкових механізмів. Метою роботи є розробка послідовностей дій для кінематичного дослідження швидкостей точок ланок складного плоского механізму четвертого класу за допомогою способу, що базується на положеннях курсу теоретична механіка про миттєвий центр швидкостей ланок механізму, що мають плоскопаралельний рух. Визначено вектори швидкостей точок ланок структурної групи четвертого класу другого порядку складного плоского механізму графоаналітичним методом, в якому умовно змінено початковий механізм, що призвело до зменшення класу механізму та дозволило виконати його дослідження.

Ключові слова: механізм; кінематичне дослідження; вектор швидкості; план швидкостей

S. Koshel, G. Koshel. Analysis of fourth class plane mechanisms with structural groups of links of the second order. The use of complex plane mechanisms in processing equipment of consumer industry is increasing. The absence of a general method of kinematic research of the fourth and higher class mechanisms allows us to accentuate the relevance of work on kinematic analysis of multilink mechanisms. Purpose of the work is to develop sequence of actions for kinematic research of velocities of the link points of a fourth class complex plane mechanism using the method based on the provisions of the "Theoretical Mechanics" course on instantaneous velocity center of links of the mechanism, which have plane-parallel motion. The velocity vectors of link points of the second order fourth class structure group of complex plane mechanism are analyzed using grapho-analytical method, which provisionally modified initial mechanism has led to a class reduction of mechanism and allowed to conduct its research.

Keywords: mechanism, kinematic research, the velocity vector, velocity vector diagram

Introduction. The technological processes of modern consumer industry produces certain criteria according to which the existing equipment of this industry should be improved or new equipment should be designed in order to ensure the competitiveness of the equipment between the manufacturers of technological machines. These requirements include: increasing the speed of processing equipment (increasing the rate speed of the main shaft), expanding the variety of functional capabilities, increasing interaction accuracy of movable objects of machines, providing complex trajectories of technology-forming elements of equipment and predetermined laws of motion (in some cases in order to ensure the technological process implementation there is need for one or two stops of a certain point of a mechanism at a predetermined time interval and in certain given positions of the machine motion cycle). The complexity of laws and movements of moving objects of the equipment, the significant speed necessitate the use of hinged structural groups with high number of links in the structural and kinematic schemes of machine mechanisms.

Improvement of existing consumer industry technological equipment and the design of new machines is connected with the perfection of methods of analysis of structural groups of links of plane mechanisms, out of which the latter are composed. The most developed are research methods of dyads or two-rail groups.

Methods of analysis of structural groups, to which four links forming a 3 class 3 order group belong, on the basis of which mechanisms of the corresponding class can be structurally synthesized, are discovered and well-known.

Structural groups of the fourth or higher class, which consist of four or more links on the one hand are already in use or have significant perspectives of application in the mechanisms of consumer industry processing equipment, on the other hand they do not have universal methods of kinematic and

\section{DOI: 10.15276/opu.1.54.2018.02}

(c) 2018 The Authors. This is an open access article under the CC BY license (http://creativecommons.org/licenses/by/4.0/). 
dynamic research. This is due to variety of structural groups that can be formed with four, six or more links and a corresponding number of kinematic pairs.

The insufficient development of methods of analyzing such structural groups is a deterrent factor of their use in technological equipment of the machine-building industries, in particular in consumer industry engineering.

Analysis of recent research and publications. A considerable number of publications of the last decades are devoted to practical use and issues of theoretical study of structural, kinematic and dynamic parameters of plane complex mechanisms of the fourth and higher classes. The use of multilevel structural link groups in certain mechanisms is protected by utility model patents $[1,2,3]$. A number of papers are devoted to theoretical analysis of the higher class mechanisms $[4,5,6,7]$, in particular to the mechanisms of consumer industry equipment $[8,9]$.

The tasks of the kinematic research of complex plane mechanisms remain relevant because in each particular case of the upper class mechanism research it is necessary to select and execute an original sequence of actions, which is caused by the simultaneous application of several methods of kinematic analysis, while a general method for studying the variety of such complex mechanisms of the fourth and higher classes does not exist at the present moment.

Purpose of the study. The purpose of the work is to develop sequence of actions for kinematic research of velocities of points that coincide with the geometric centers of kinematic pairs of the second order fourth class structural group with a movable closed loop formed by three connecting rods and one rocker arm, based on provisions of the course of the theory of mechanisms and machines on the structural property of mechanisms with structural groups to change the class depending on the conditionally selected other possible initial mechanism, that becomes part of the structure of driven links of the mechanism, provisions on "singular points" and applies the method of theoretical mechanics course on kinematic study of the material points mechanical system with instantaneous velocity center (I.V.C.).

Presentation of the main material. Let us consider complex plane articulation linkage of the fourth class (Figure), that consists of driving link 1, which is connected to a stand-pipe 0 and other driven links $2 \ldots 5$, among which links $2 \ldots 4$ are connecting rods, 5 - rocker arm. The initial mechanism (links 0,1$)$ together with the fourth class second order structural group, which consists of a set of four links $2 \ldots 5(n=5)$ along with six kinematic pairs of the fifth class $A, B, C, D, E, K\left(p_{5}=6\right)$ form a fourth class mechanism with a degree of freeness equal to 1 according to the Chebyshev formula: $W=3 n-2 p_{5}-p_{4}$, that is form a mechanism with one driving crank. The formula of the complex mechanism structure that is being studied has the following form: 1 class (links 0,1$) \rightarrow 4$ class 2 order (links 2 ...5) .

The structural feature of the mechanism is the presence of a shape-variable closed loop $B, C, D, E$ formed by three connecting rods $B C, B D, C E$ and one rocker arm $D E$, in which one of the connecting rods located opposite the rocker arm and the rocker arm itself have the form of complex links (connecting rod 2 and rocker arm 5 together with other links form 3 kinematic pairs each). It is not possible to perform a kinematic analysis of the mechanism using known research methods of the third class complex mechanisms by grapho-analytical method. It is due to the fact that the connecting rod 2 , which is directly attached to the crank 1 , is linked to two connecting rods 3,4 from the other side, the kinematic parameters of such points and their trajectories are unknown.

The input parameters for kinematic research of the mechanism are the angular velocity of the crank $1\left(\omega_{1}=\right.$ const, $\left.\mathrm{c}^{-1}\right)$ and the length scale $(\mathrm{Kl}, \mathrm{m} / \mathrm{mm})$ of the kinematic scheme of the mechanism.

Let us use the grapho-analytical method of kinematic research. The problem is solved using general provisions of the kinematic analysis of mechanisms of the "Theory of Mechanisms and Machines" course and the provisions of the "Theoretical mechanics" course, in relation to the study of the plane-parallel motion of a solid body.

The structural property of the higher class mechanisms to switch class under condition of change of the initial mechanism by another possible conditional mechanism of the first class is taken into account [10]. It is clear that a case would be useful if such a change led to a reduction in the class of the mechanism. 
The only possible alternative is chosen for the original mechanism - a set of links 0,5 . The mechanism takes the form of a third class mechanism, the structure of which is described by the following formula:

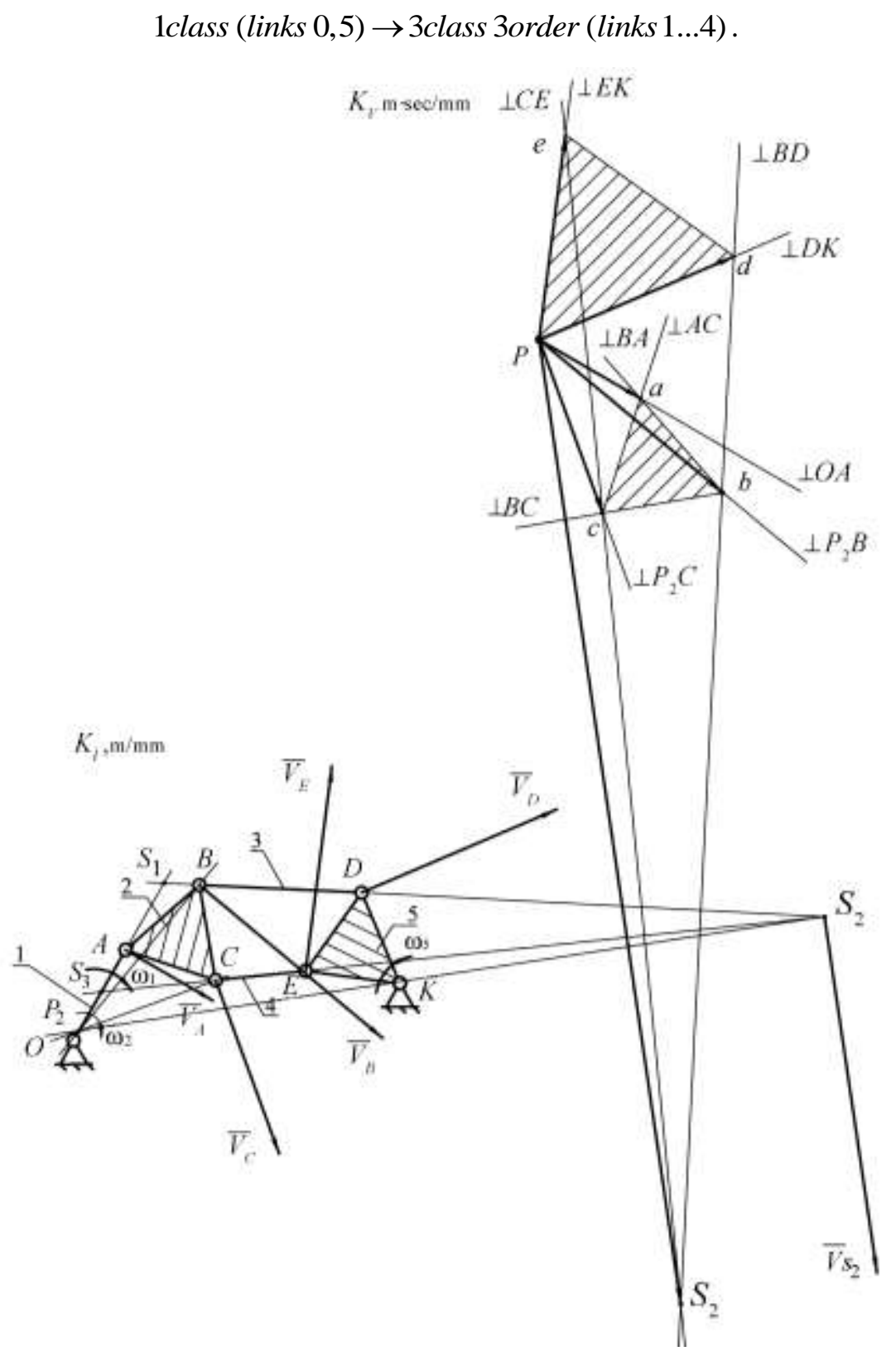

Fig. Kinematic scheme and velocity vector diagram of the fourth class mechanism

The kinematic research begins when the angular velocity $\omega_{5}$ of the rocker arm 5 is arbitrarily assigned in magnitude and direction similar to a link, which according to the formula of the structure of the mechanism is another arbitrarily possible driving link of the mechanism: on the velocity diagram let us mark vectors $\vec{P} d$ of arbitrary length in the direction along the perpendicular to the line $D K$, the direction of the angular velocity $\omega_{5}$ is selected arbitrarily, for example clockwise. According to the similarity theorem, we determine the position of the point " $\mathrm{e}$ " on the velocities diagram. On the kinematic scheme we define the positions of the "singular points" $S_{1}, S_{2}, S_{3}$, as points of paired crossing of segments: $O, A$ and $B, D ; C, E-B, D ; O, A-C, E$. The system of vector equations for determining the speed of point $S_{2}$ is made up: 


$$
\left\{\begin{array}{l}
\vec{V}_{S 2}=\vec{V}_{B}+\vec{V}_{S_{2} ; B}=\vec{V}_{D}+\vec{V}_{B ; D}+\vec{V}_{S_{2} ; B} \\
\vec{V}_{S 2}=\vec{V}_{C}+\vec{V}_{S_{2} ; C}=\vec{V}_{E}+\vec{V}_{C ; E}+\vec{V}_{S_{2} ; C}
\end{array}\right\} .
$$

Let us solve the system of equations and find the vector of velocity $\vec{P} S_{2}$ on the diagram, which, using parallel shift, is constructed in the point $S_{2}$ of the position plan of the mechanism. According to known directions of $\vec{V}_{S_{2}}, \vec{V}_{A}$ velocity vectors of two points $S_{2}$ and A of the connecting rod 2, we determine the position of link 2 I.V.C. (point $P_{2}$ ), as the point of intersection of perpendiculars to vectors $\vec{V}_{S_{2}}, \vec{V}_{A}$, that are constructed from points $S_{2}$ and A respectively.

Then let us use the condition of belonging the points $P_{2}, A, B, C$ to one link 2 having a planeparallel motion and the fact that the position of the point $P_{2}$ is found for determining the directions of velocity vectors $\vec{V}_{B}, \vec{V}_{C}$ of points $B, C$. The vectors $\vec{V}_{B}, \vec{V}_{C}$ are directed along the perpendiculars to the segments $P_{2}, B$, and $P_{2}, C$ respectively in the direction of the instantaneous rotational angular velocity of the connecting rod 2. According to the theorem on determining the velocities of points of a body having a plane-parallel motion, the lengths of velocity vectors on the diagram will be proportional to the corresponding distances of these points to I.V.C. link position.

A system of vector equations that allows us to determine the lengths of vectors $\vec{V}_{C}, \vec{V}_{B}$ on the velocity vector diagram based on the constructed velocity vectors of the points $E$ and $D$ is proposed:

$$
\left\{\begin{array}{l}
\vec{V}_{C}=\vec{V}_{E}+\vec{V}_{C ; E} \\
\vec{V}_{C} \perp P_{2} C
\end{array}\right\}, \quad\left\{\begin{array}{l}
\vec{V}_{B}=\vec{V}_{D}+\vec{V}_{B ; D} \\
\vec{V}_{B} \perp P_{2} B
\end{array}\right\},
$$

where $\vec{V}_{C ; E} \perp C E, \vec{V}_{B ; D} \perp B D$.

The further solution is to select such length of the velocity vector $\vec{V}_{A}$ of point A that it satisfies the condition of the arbitrarily accepted value of the angular velocity of the connecting rod 5 . The velocity $\vec{V}_{A} \perp O A$ is directed toward the direction of the given angular velocity $\omega_{1}$ of the actual driving link of the mechanism, and the line of possible actual positions of the point " $a$ " on the diagram is the line drawn through the pole $P$ in the direction perpendicular to the center line of the $O A$ link. On the other hand in order to determine the position of the point " $a$ " on the diagram the following system of vector equations is offered:

$$
\left\{\begin{array}{l}
\vec{V}_{A}=\vec{V}_{C}+\vec{V}_{A ; C} \\
\vec{V}_{A}=\vec{V}_{B}+\vec{V}_{A ; B}
\end{array}\right\},
$$

where $\vec{V}_{A ; C} \perp A C, \vec{V}_{A ; B} \perp B A$.

After solving the system of equations (3) we find a vector $\vec{P}_{a}$, the point " $a$ " of which is located on a line passing through the pole $P$ of the velocities diagram and perpendicular to the crank $O A$ in the direction of the angular velocity $\omega_{1}$, which confirms the correctness of the problem solution.

The resulting velocity diagram is perceived as a graphical construction where the vectors of linear velocities of the points of the fourth class second order mechanism are constructed from a pole at an indefinite scale, which, in terms of the given size of the links and the angular velocity of the actual driving link, is not difficult to calculate.

It should be noted that in contract with the known method of false assertions, which is used for similar researches of structural groups of the third class and after obtaining the actual velocity of one point of the complex link of the structural group requires to rebuild the diagram in order to determine the actual velocities of all other points of the mechanism, the proposed sequence of kinematic analysis allows researching the mechanisms of the fourth class without having to rebuild the diagram that was 
built on an indefinite scale, and lets us select the magnitude of linear velocity vector of point $\mathrm{A}$ of a crank followed by calculation of real scale parameter of the completed graphical construction.

Conclusions. The sequence of actions was developed and the kinematic research of velocities of points of the fourth class mechanism with a movable closed loop formed by three connecting rods and one rocker arm, two of which are complex links, was carried out based on the structural property of the higher-order mechanisms to change the class due to the selection of another potential initial mechanism, which made it possible to perform a kinematic analysis provided that the volume of graphic constructs of the study is optimized. The proposed sequence of kinematic analysis can be recommended for similar researches of complex plane mechanisms of the fourth and higher classes.

\section{Література}

1. Кривошипно-ползунный механизм пресса: пат. 2201348 Российская Федерация: № 2001120227/02; заявл. 18.07.2001; опубл. 27.03.03., Бюл. 9.5 с.

2. Секция механизированной крепи: пат. 2303699 Российская Федерация: № 2005141748/03; заявл. 30.12.2005; опубл. 27.07.2007.

3. Двухщековая дробильная машина: пат. 2332260 Российская Федерация: № 2007101108/03 заявл. 09.01.2007; опубл. 27.08.2008.

4. Кикин А.Б., Пейсах Э.Е. Аналитико-оптимизационный синтез шестизвенного механизма с выстоем. Известия высших учебных заведений. Технология текстильной промышленности. 2008. № 5. С. $79-83$.

5. Дворников Л.Т., Стариков С.П. Исследование кинематики и кинетостатики плоской шарнирной шестизвенной группы Ассура с четырехугольным замкнутым изменяемым контуром. Известия высших учебных заведений. Машиностроение. 2008. №4. С. 3-10.

6. Чашников Д.О., Гаряшин В.В. Кинематическое исследование плоского восьмизвенного механизма шестого класса с поступательной парой. Успехи современного естествознания. 2011. № 7. С. 231-232.

7. Чашников Д.О., Гаряшин В.В. Кинематическое исследование плоского восьмизвенного механизма шестого класса с поступательной парой аналитическим методом. $y_{c n e x u}$ современного естествознания. 2012. №6. С. 158-159.

8. Гебель Е.С., Солонин Е.В. Моделирование кинематики механизма игл основовязальной машины. Теоретические знания в практические дела: сборник материалов $\mathrm{X}$ междунар. научно-практ. конф.: в 2 ч. Омск.: 2009. Ч. 2. С. 211-215.

9. Кикин А.Б. Синтез рычажных механизмов для привода нитераскладчика мотальной машины. Известия высших учебных заведений. Технология текстильной промышиленности. 2005. № 1. C. $115-119$.

10. Кошель С.О., Кошель Г.В. Структурний аналіз складних плоских механізмів четвертого класу. Вісник Хмельницького національного університету. Технічні науки. 2015. №1. С. 72-79.

\section{References}

1. Dvornikov L.T., Chuzhikov O.S., \& Starikov S.P. (2001). Slider-crank mechanism for the press. Russian Federation Patent: RU 2201348.

2. Dvornikov L.T., Knyazev A.S., \& Starikov S.P. (2005). Section mechanized system. Russian Federation Patent: RU 2303699.

3. Dvornikov L.T., \& Starikov S.P. (2007). Double Jaw Crushing Machine. Russian Federation Patent: RU 2332260.

4. Kikin A.B. \& Pejsah Je.E. (2008). Analytical and optimal synthesis of six-membered mechanism with dwell. Proceedings of Higher Education Institutions: Technology textile industr, 5, 79-83.

5. Dvornikov L.T. \& Starikov S.P. (2008). The study of kinematics and Kinetostatics flat hinged sixmembered group Assur quadrangular closed loop variable. Proceedings of Higher Education Institutions: Engineering, 4, 3-10.

6. Chashnikov D.O. \& Garyashin V.V. (2011). Kinematic study of planar six sixth grade mechanism with sliding pair. Uspehi sovremennogo estestvoznaniya, 7, 231-232. 
7. Chashnikov D.O. \& Garyashin V.V. (2012). Kinematic study of planar six sixth grade mechanism with sliding pair analytical method. Advances in Current Natural Sciences, 6, 158-159.

8. Gebel E.S. \& Solonin E.V. (2009). Kinematics modeling of needle mechanism of warp- knitting machine. In Proceedings of $10^{\text {th }}$ International Scientific and Practical Conference "Theoretical Knowledge - into Practice” (Vol. 2, pp. 211-215). Omsk: MSUTM named after K.G. Razumovsky.

9. Kikin A.B. (2005). Linkages synthesis to drive of the thread spreading for a winding machine. Proceedings of Higher Education Institutions:Technology textile industry, 1, 115-119.

10. Koshel S.O. \& Koshel G.V. (2015). Structural analysis of complex flat mechanisms fourth class. Herald of Khmelnytskyi National University: Technical Sciences, 1, 72-79.

Кошель Сергій Олександрович; Koshel Sergey, ORCID: https://orcid.org/0000-0001-7481-0186

Кошель Ганна Володимирівна; Koshel Ganna, ORCID: https://orcid.org/0000-0003-1862-1553

Received October 29, 2017

Accepted January 11, 2018 